\title{
MERCATORIA
}

Available online http://ojs.uma.ac.id/index.php/mercatoria

\section{Keberadaan Arbitrase di Kota Medan}

\author{
Taufik Siregar *
}

Universitas Medan Area

*Corresponding author: E-mail: taufiksiregar@uma.ac.id

\begin{abstract}
Abstrak
Penelitian ini bertujuan untuk mengetahui keberadaan lembaga arbitrase, yaitu dari dibuatnya klausula arbitrase sampai penyelesaian sengketa bisnis dengan cara-cara arbitrase. Juga untuk mengetahui bentuk dan badan arbitrase yang lebih diminati, serta hambatan-hambatan didalam penggunaan lembaga arbitrase dikalangan pelaku usaha Kota Medan. Hasil penelitian menunjukkan, bahwa kalangan pelaku usaha umumnya telah mengetahui lembaga arbitrase tetapi belum begitu memahaminya, sehingga belum menjadikan lembaga arbitrase sebagai pilihan utama dalam menyelesaikan sengketa bisnis. Badan arbitrase institusional adalah bentuk lembaga arbitrase yang diminati kalangan pelaku usaha, dengan alasan badan arbitrase institusional telah menyediakan arbiter yang akan menyelesaikan sengketa bisnis tersebut.
\end{abstract}

Kata kunci : Arbitrase, penyelesaian, sengketa, dunia usaha

\begin{abstract}
This study aims to determine the existence of arbitration institutions, namely from arbitration clauses to the settlement of business disputes by means of arbitration. Also to know the form and the arbitration body more desirable, as well as obstacles in the use of arbitration institutions among business players Medan City. The result of the research shows that business actors generally already know the arbitration institution but have not understood it yet, so it has not made the arbitration institution as the main choice in resolving the business dispute. The institutional arbitration body is a form of arbitration institution in favor of business actors, on the grounds that the institutional arbitration body has provided an arbitrator who will resolve the business dispute.
\end{abstract}

Keyword: Arbitration, dispute resolution, business world

How to Cite: Siregar, T., (2018), Keberadaan Arbitrase di Kota Medan, Mercatoria, 11 (1): 20-36. 


\section{PENDAHULUAN}

Pada waktu membahas Konvensi Den Haag tentang jual beli internasional, kalngan pedagang Jerman menganggap hukum dari negara-negara yang sedang berkembang (termasuk Indonesia) sangat sulit untuk dipahami, sebagai jalan keluar dari kesulitan tersebut, dianjurkan agar dalam kontrak-kontrak bisnis dicantumkan klausula arbitrase (Sudargo Gautama, 1976 : 32)

Bertitik tolak dari uraian di atas, maka dapat diketahui bahwa para mitra bisnis dari negara-negara maju umumnya mencantumkan klausula arbitrase pada kontrak bisnis yang dibuat. Maka, hal ini harus menjadi perhatian yang serius kalangan dunia usaha Indonesia. Khusunya, kalangan dunia usaha di Kota Medan agar dapat mengikuti globalisasi perdagangan internasional. Dalam artibrase, para pihak dapat memilih hakim (arbiter) yang diinginkan, berbeda dengan system litigasi di pengadilan yang telah menetapkan hakim yang akan menyelesaikan sengketa. Dengan demikian, hal tesebut memberi jaminan kenetralan maupun keahlian yang diperlukan para pihak dalam meyelesaikan sengketa. Para pihak juga dapat memilih hukum yang akan diterapkan pada sengketa tersebut. Sifat arbitrase yang demikian, akan melindungi para pihak yang merasa takut atau tidak yakin dengan substansi hukum jurisdiksi tertentu. Kerahasiaan dari arbitrase, membantu melindungi para pihak dari usaha pembocoran rahasia yang dapat merugikan para pihak yang bersengketa, seperti halnya dalam proses litigasi di pengadilan (Gary Goodpaster dkk, 1995: 7-8)
Ditinjau dari segi komersial atau bisnis, arbitrase dipandang sebagai lembaga penyelesaian sengketa yang tepat. Seperti yang dikemukakan Pierre Lalive, bahwa dengan menyelesaikan suatu sengketa bisnis melalui lembaga arbitrase, para pihak diupayakan untuk bisa tetap berhubungan bisnis di masa depan. Dengan demikian, cara penyelesaian sengketa melalui lembaga arbitrase mengupayakan agar para pihak tidak bermusuhan, tetapi tetap memelihara hubungan bisnis mereka, setelah sengketanya diputus oleh arbiter yang telah dipilih. Maksudnya, para pihak tetap berhubungan bisnis dengan baik setelah sengketanya diselesaikan melalui lembaga arbitrase (Huala Adolf, 1994:3).

Berkaitan dengan hal tersebut, Sudargo Gautama (1986:2) juga mengemukakan beberapa keuntungan di dalam mempergunakan lembaga arbitrase yaitu: bahwa lembaga arbitrase yang sifatnya "private" memberikan jaminan terhindarnya penyelesaian sengketa dari publisitas. Sengketa-sengketa bisnis yang diselesaikan melalui lembaga arbitrase sifatnya tidak umum, seperti halnya dalam penyelesaian sengketa bisnis melalui pengadilan yang dapat diketahui oleh umum. Proses penyelesaian sengketa bisnis di pengadilan dapat diikuti oleh umum dan keputusannya juga diucapkan di dalam siding terbuka, sehingga dapat dipublikasikan di media massa. Tidak demikian halnya dengan prosedur penyelesaian sengketa bisnis melalui lembaga arbitrase, di mana pertimbangapertimbangan para arbiter sifatnya rahasia dan tidak lazim secara lengkap diumumkan dalam media massa. Para pelaku usaha, umunya khawatir 
berperkara di pengadilan karena adanya publisitas ini.

Lebih lanjut dikemukan beliau, bahwa prosedur penyelesaian sengketa melalui lembaga arbitrase, tidak banyak mengenal formalitas seperti halnya berperkara di pengadilan. Beracara di depan pengadilan di dalam perkara perdata terikat oleh berbagai formalitas, sedangkan beracara secara arbitrase formalitasnya hanya diperlukan, apabila pihak yang kalah tidak secara sukarela memenuhi keputusan yang diberikan arbiter, sehingga diperlukan bantuan dari pengadilan untuk mengeksekusinya. Tetapi, apabila keputusan yang diberikan arbiter ditaati para pihak, maka tidak perlu adanya campur tangan dari pengadilan dengan segala formalitas atau syarat-syarat yang diperlukan, untuk pengeksekusian keputusan arbitrase tersebut.

Sifat-sifat dari lembaga arbitrase tersebut di atas, sangat sesuai dengan karakter hukum yang dibutuhkan kalangan dunia usaha. Dengan demikian, lembaga arbitrase dapat diharapkan sebagai lembaga penyelesaian sengketa alternatif yang lebih diminati kalangan pelaku usaha dari pada proses litigasi di pengadilan.

Permasalahan dalam penelitian ini yaitu :

1. Bagaimanakah keberadaan lembaga arbitrase di kalangan pelaku usaha di Kota Medan?

2. Bentuk dan badan arbitrase manakah yang lebih diminati kalangan pelaku usaha di Kota Medan?
3. Mengapa lembaga arbitrase kurang dipergunakan kalangan pelaku usaha di Kota Medan?

\section{METODE PENELITIAN}

Penelitian ini merupakan penelitian deskriptif analitis, dengan metode pendekatan juridis sosiologis yakni berkeinginan melihat pandangan pelaku usaha di Kota Medan akan pentingnya keberadaan arbitrase, serta pelaksanaan arbitrase itu sendiri. Alat yang dipergunakan untuk mengumpulkan data, ialah pedoman wawancara (interviewguide) dan kuesioner yang ditujukan kepada responden. Kuesioner yang dipergunakan bersifat setengah terbuka dan tertutup (projective questionaire).

Setelah data primer dan data sekunder berhasil dikumpulkan, selanjutnya dilakukan pengeditan. Hal ini dilakukan agar ketepatan data dapat dicek dan dapat diperbaiki, dengan jalan menjajaki kembali ke sumber datanya.

Setelah proses pengeditan selesai, maka diadakan pengkodean data (coding) dan seterusnya data ditabulasi ke dalam tabel-tabel yang dipersiapkan. Langkah ini dilakukan dengan tujuan untuk memisahkan data yang tidak relevan dari data yang dibutuhkan sekaligus untuk melihat validitas dan konsistensi data.

Data yang sudah ditabulasi, kemudian dianalisis secara logis, sistematis, serta data ditafsirkan dengan mempergunakan pendekatan kualitatif yuridis maksudnya seluruh data secara utuh dihubungkan dengan peraturanperaturan hukum yang berkaitan dengan lembaga arbitrase. Dengan cara ini diharapkan dapat menjawab 
permasalahan-permasalahan yang diajukan dalam penelitian.

\section{HASIL DAN PEMBAHASAN}

Arbitrase diatur secara umum berdasarkan Reglement of de Burgerlijke Rechtscvordering (Rv), tetapi di dalam peraturan tersebut tidak dijumpai satu pasal, yang khusus memberikan pengertian arbitrase.

Beberapa ahli hukum telah memberikan pengertian arbitrase, di antaranya adalah:

1. Subekti (1981:1) mengatakan, bahwa perkataan arbitrase berasal dari kata "Arbitrare" (bahasa Latin), yang berarti kekuasaan untuk menyelesaikan suatu perkara menurut kebijaksaan, dapat menimbulkan salah pengertian tentang arbitrase. Ada kesan seolah-olah seorang arbiter atau majelis arbitrase, dalam menyelesaikan sengketa tidak mengindahkan norma-norma hukum lagi dan menyandarkan pemutusan sengketa dengan kebijaksanaan saja. Kesan tersebut adalah keliru, karena arbiter atau majelis arbitrase tersebut, juga menerapkan hukum seperti apa yang dilakukan oleh hakim di pengadilan.

2. Menurut Frank Elkoury dan Edna Elkoury dalam buku mereka "How Arbitration Works", Washington D.C., tahun 1974, arbitrase adalah suatu proses yang mudah dan simple, dipilih oleh para pihak secara sukarela yang ingin, agar perkaranya diputus oleh juru pisah yang netral sesuai dengan pilihan mereka, putusan yang diberikan mereka berdasarkan dalildalil dalam perkara tersebut. Para pihak setuju sejak semula untuk menerima putusan tersebut secara final dan mengikat ( M. Husseyn Umar dan A. Supriyani Kardono, 1995:2 )

3. HMN. Purwosutjipto mengatakan, bahwa perwasitan adalah peradilan, yang para pihak sepakat agar perselisihan mereka tentang hak pribadi yang dapat mereka kuasai sepenuhnya, diperiksa dan diadali oleh hakim yang tidak memihak, yang ditunjuk oleh para pihak sendiri dan putusannya mengikat bagi kedua belah pihak.

\section{Dasar Hukum Arbitrase di Indonesia}

Di Belanda dan di Jepang dasar hhukum bagi arbitrase terdapat dalam undang-undang hukum acara, sedangkan di beberapa negara lain masalah arbitrase di atur dalam undang-undang arbitrase tersendiri. Misalnya Swedia yang mempunyai Arbitration Act tahun 1929, Inggris mempunyai Arbitration Act tahun 1950, dan sebagainya (Sudargo Gautama, 1974:10).

Dasar hukum arbitrase di Indonesia, awalnya harus melihat kepada pasal II Aturan Peralihan dalam UUD 1945 yang menyebutkan "Segala baadan negara dan peraturan yang ada masih langsung berlaku, selama belum diadakan yang baru menurut Undang-undang Dasar ini".

Berdasakan ketentuan peralihan ini, maka masih tetap diakui keabsahan dan keberadaan peraturan perundangundangan yang telah ada, sampai diadakan yang baru sebagai penggantinya.

Bertitik tolak dari pasal II Aturan Peralihan UUD 1945, dikaitkan dengan permasalahan hukum yang menyangkut 
arbitrase, maka dasar hukum selanjutnya adalah Pasal 377 HIR atau Pasal 705 RBG.

HIR merupakan hukum acara perdata yang berlaku pada lingkungan peradilan umum untuk daerah Jawa dan Madura, serta RBG untuk daerah luar Jawa dan Madura/daerah seberang.

Menurut M. Yahya Harahap (1991:21), bahwa HIR dan RBG samasama memperkenankan:

1. Menyelesaikan sengketa melalui juru pisah (arbiter).

2. Arbiter diberi fungsi dan wewenang untuk menyelesaikan sengketa dalam bentuk keputusan.

3. Para pihak maupun arbiter, wajib tunduk menuruti peraturan hukum acara yang berlaku bagi bangsa Eropa.

Tegasnya Pasal 377 HIR atau 705 RBG menyebutkan "Jika orang Indonesia dan orang Timur Asing menghendaki perselisihan mereka diputus oleh juru pisah, maka mereka wajib menuruti peraturan perkara yang berlaku bagi bangsa Eropa".

Dari bunyi pasal di atas, jelas memberi kemungkinan bagi para pihak yang bersengketa untuk menyelesaikan perkaranya di luar pengadilan, apabila mereka menghendakinya. Penyelesaian dan keputusannya dapat mereka serahkan sepenuhnya kepada juru pisah (arbiter), yang oleh undang-undang diberi kewenangan untuk memutusnya.

HIR atau RBG tidak memuat aturan lebih lanjut tentang arbitrase. Untuk mengisi kekosongan aturan hukum tentang arbitrase, Pasal 377 HIR dan Pasal 705 RBG langsung menunjuk aturan pasalpasal arbitrase yang terdapat dalam Reglemen Hukum Acara Perdata (Reglement op de Bergerlijke
Rechtsvordering, disingkat Rv, S. 1874-52 jo S. 1849-63). Hal ini jelas terdapat dalam kalimat :"... wajib menuruti peraturan pengadilan perkara yang berlaku bagi bangsa Eropa". Sedangkan peraturan hukum acara yang berlaku bagi bangsa Eropa di depan Raad van Justitie ialah Rv, sehingga $\mathrm{Rv}$ berlaku juga bagi golongan penduduk Bumiputra dan Timur Asing, apabila mereka ingin menyelesaikan persengketaan yang timbul melalui badan arbitrase.

Peraturan mengenai arbitrase di dalam $\mathrm{Rv}$ tercantum dalam buku ketiga bab pertama, Pasal 615 sampai dengan Pasal 651 yang meliputi lima bagian pokok yaitu:

1. Pasal 615-623, mengatur persetujuan arbitrase dan pengangkatan arbiter.

2. Pasal 624-630, mengatur pemeriksaan di muka arbiter.

3. Pasal 631-640, mengatur putusan arbitrase.

4. Pasal 641-647, mengatur upaya-upaya terhadap putusan arbitrase.

5. Pasal 648-651, mengatur berakhirnya acara arbitrase.

Demikian sistematika aturan arbitrase yang terdapat dalam Reglemen Acara Perdata atau Rv yang wajib dituruti.

Sampai sekarang belum ada peraturan perundang-undangan baru yang dikodifikasi tentang arbitrase, maka berdasarkan Pasal II Aturan Peralihan UUD 1945 jo Pasal 377 HIR atau Pasal 705 RBG, Buku Ketiga Bab Pertama Rv tetap berlaku menjadi peraturan perundangundangan arbitrase, dalam tata hukum di Indonesia. Fungsinya menjadi aturan umum arbitrase di Indonesia.

Memperhatikan sistematika yang terdapat di dalam Rv, mungkin pada saat 
pembuatannya di tahun 1849 sudah memenuhi kebutuhan hukum masyarakat. Tetapi melihat pesatnya laju pertumbuhan perdagangan, terutama perdagangan internasional jelas $\mathrm{Rv}$ sudah sangat ketinggalan.

Selanjutnya dasar hukum arbitrase di Indonesia, terdapat di dalam Penjelasan Pasal 3 ayat (1) UU No. 14 Tahun 1970 Undang-undang Pokok Kekuasaan Kehakiman yang meneybutkan "Penyelesaian perkara di luar pengadilan atas dasar perdamaian atau melalui wasit (arbiter) tetap diperbolehkan."

Dengan memori penjelasan Pasal 3 ayat (1) UU No.14 Tahun 1970 di atas, maka tidak ada keraguan atas legalitas dan peran arbitrase dalam tata hukum Indonesia. Para pihak yang mengadakan perjanjian hubungan perdagangan, dapat mengadakan kesepakatan untuk menyerahkan penyelesaian persengketaan yang timbul kepada lembaga arbitrase.

Dasar hukum keberadaan lembaga arbitrase, juga ditemukan pada Pasal 80 Undang-undang No. 14 Tahun 1985 tentang Mahkamah Agung, yang menyebutkan:

Semua peraturan pelaksaan yang telah ada mengenai Mahkamah Agung dinyatakan tetap berlaku, selama ketentuan yang baru belum dikeluarkan dan sepanjang peraturan tersebut tidak bertentangan dengan Undang-undang Mahkamah Agung ini.

\section{Dasar Hukum Arbitrase Asing di Indonesia}

Pemerintah Indonesia telah memperlihatkan kehendak politik hukum di bidang arbitrase asing, berupa pernyataan pengakuan berlakunya beberapa konvensi arbitrase internasional di Indonesia. Pernyataan pengakuan arbitrase asing diberikan berdasarkan Undang-undang, Keppres, dan Perma.

Berdasarkan UU No. 5 Tahun 1968, Pemerintah Indonesia memberikan persetujuan berlakunya Konvensi tentang Penyelesaian Perselisihan antara Negara dan Warga Negara Asing Mengenai Penanaman Modal (Convention on the Suttlement of Investment Disputes Between State and National of Other State). Konvensi ini lazim disebut Konvensi Bank dunia (World Bank Convention) serta disingkat menjadi Internasional Centre for the Settlement of Investment Disputes (ICSID) atau Centre.

Tujuan Pemerintah Indonesia memberikan persetujuan atas konvensi ini adalah untuk mendorong dan membina perkembangan penanaman modal asing di Indonesia. Sebab, dengan diakuinya ICSID oleh Pemerintah Indonesia akan memberikan keyakinan kepada penanaman modal asing, bahwa sengketa yang timbul akan ke forum arbitrase.

Dasar hukum lain berlakunya arbitrase asing di Indonesia ialah Keputusan Presiden (Keppres) No. 34 Tahun 1981. Keppres ini bertujuan memasukkan "Convention on the Recognition and Enforcement of Foreign Arbitral Award", yang lazim disebut Konvensi New York 1958 ke dalam tata hukum intern Indonesia.

Konvensi New York 1958, merupakan peraturan yang mengatur tentang pengakuan dan eksekusi putusan arbitrase asing oleh negara yang mengikatkan diri padanya.

Berarti, sejak berlakunya Keppres No. 34 Tahun 1981 tanggal 5 Agustus 
1981, maka Indonesia telah mengikatkan diri dengan suatu kewajiban hukum untuk mengakui dan mematuhi pelaksanaan eksekusi atas setiap putusan arbitrase asing. Namun demikian, pengakuan dan kewajiban hukum itu, tidak terlepas penerapannya dari atas resiprositas, yakni asas timbal balik antara negara yang bersangkutan dengan Negara Indonesia. Kesediaan Negara Indonesia mengakui dan menjalankan putusan arbitrase asing harus berlaku timbal balik dengan pengakuan dan kerelaan negara lain tersebut, menjalankan putusan arbitrase yang diminta oleh pihak Indonesia. Dengan kata lain, sikap pengakuan dan kerelaan pihak Indonesia menjalankan putusan arbitrase asing, atas permintaan yang datang dari suatu negara lain, harus didasarkan atas ikatan bilateral dan multilateral. Tidak bisa dipaksakan secara unilateral. Sekurang-kurangnya, antara negara yang meminta pengakuan dan eksekusi putusan, sudah lebih dahulu memliki ikatan perjanjian dengan Indonesia, baik secara bilateral maupun multilateral. Pihak Indonesia tidak terikat untuk mengakui dan menjalankan putusan arbitrase asing, jika pihak negara lain yang memintanya tidak terikat secara bilateral atau multilateral dengan Pemerintah Indonesia.

Tujuan Konvensi New York 1958, adalah untuk meningkatkan hubungan kerjasama di antara negara-negara atau masyarakat internasional terhadap masalah-masalah arbitrase. Dengan konvensi ini, masyarakat internasional diajak untuk mengakui dan bersedia melaksanakan setiap putusan yang diambil oleh forum arbitrase di luar teritorial suatu negara. Dengan kata lain, setiap negara diharapkan mengakui (recognation) dan menjalankan (enforcement) setiap putusan arbitrase yang dijatuhkan di luar negeri. Harapan ini didasarkan pada asumsi, putusan arbitrase lebih bersifat objektif, karena hukum yang diterapkan tidak terikat pada system tata hukum dari salah satu negara yang sedang berselisih. Juga diharapkan, dengan adanya pengakuan yang merata di antara semua negara atas putusan arbitrase asing, hubungan lalu lintas perdagangan internasional atau joint venture, akan lebih cepat dan lebih sederhana cara penyelesaiannya.

Berdasarkan Keppres No. 34 Tahun 1981, tata hukum Indonesia telah mengakui putusan arbitrase yang dijatuhkan di luar negeri. Bersamaan dengan pengakuan tersebut, maka peradilan Indonesia harus melaksanakan putusanarbitrase asing apabila hal itu diminta oleh negara asing yang mnempunyai ikatan perjanjian dengan Indonesia.

Di dalam Pasal 17 ayat (1) RUU tentang Arbitrase disebutkan, bahwa putusan yang dibuat di negara yang turut serta pada Konvensi mengenai Pengakuan dan Pelaksanaan Putusan Arbitrase Asing tertangggal 10 Juni 1958 diakui dan akan dilaksanakan sesuai ketentuan-ketentuan dalam konvensi tersebut.

Perbedaan antara UU No. 5 Tahun 1968 dengan Keppres No. 34 Tahun 1981, dihubungkan dengan masalah pengakuan (recognition) dan pelaksanaan (enforcement) putusan arbitrase asing, dapat dilihat dari segi jangkauannya. Pada UU No. 5 Tahun 1968, sepanjang mengenai perselisihan yang menyangkut penanaman modal asing atau joint venture melalui 
forum arbitrase ICSID. Lain halnya dengan Keppres No. 34 Tahun 1981, dengan keppres ini, pengakuan dan pelaksanaan eksekusi putusan arbitrase asing, pada prinsipnya meliputi segala putusan arbitrase yang dijatuhkan di luar wilayah hukum negara Indonesia.

\section{UNCITRAL Arbitration Rules Tahun 1976}

UNCITRAL (United Nations Commision on Internasional Trade Law), merupakan Panitia PBB tentang Hukum Dagang Internasional. Salah satu karyanya adalah UNCITRAL Arbitration Rules (Kaidah-kaidah Arbitrase dari Komisi PBB tentang Hukum Dagang Internasional).

Tujuan PBB melahirkan UNCITRAL Arbitration Rules adalah untuk mengglobalisasikan serta menginternasionalisasikan nilai-nilai dan tata cara arbitrase dalam menyelesaikan sengketa yang terjadi dalam hubungan perdagangan internasional. Resolusi tersebut menganjurkan kepada setiap negara dan pengguna jasa arbitrase, agar mempergunakan UNCITRAL Arbitration Rules sebagai pedoman aturan yang diterapkan dalam penyelesaian sengketa melalui arbitrase.

Mengadopsi UNCITRAL Arbitration Rules ke dalam tata hukum nasional, merupakan suatu kebijaksanaan pemerintah Indonesia untuk mengantisipasi perkembangan perdagangan internasional yang begitu pesat. Karena perdagangan internasional sangat membutuhkan peraturan arbitrase yang seragam (uniform), untuk dapat melindungi pelaksanaan transaksitransaksi perdagangan internasional.
Perma No. 1 Tahun 1990 tentang Tata

\section{Cara Putusan Arbitrase Asing}

Peraturan Mahkamah Agung No. 1 Tahun 1990 (disingkat Perma No. 1 Tahun 1990) tentang Tata Cara Putusan Arbitrase Asing, sudah lama dinantikan kehadirannya. Karena meskipun melalui Keppres No. 34 Tahun 1981, Pemerintah Indonesia telah melakukan pengesahan terhadap Konvensi New York 1958, ternyata pihak peradilan di Indonesia selalu menolak eksekusi terhadap putusan arbitrase asing.

Menurut Sudargo Gautama (1991:1), bahwa Konvensi New York dari PBB tahun 1958 yang oleh Keppres No. 34 Tahun 1981, Lembaran Negara 1981 No. 40 tertanggal 5 Agustus 1981 telah disahkan pula untuk berlaku bagi Republik Indonesia, sesungguhnya tidak memerlukan lagi suatu peraturan tersendiri karena merupakan suatu Treaty yang sifatnya "Self Executing". Jadi, sesungguhnya tidak diperlukan lebih lanjut suatu peraturan pelaksanaan yang dikeluarkan oleh Pemerintah Indonesia. Karena dalam konvensi itu sendiri tercantum, bahwa cara pelaksanaan putusan arbitrase dalam negeri anggota konvensi ini. Jadi cara untuk melaksanakan putusan dari BANI (Badan Arbitrase Nasional Indonesia) yang diputuskan dalam wilayah Republik Indonesia. Cara pelaksanaannya adalah melalui Pengadilan Negeri yang meliputi wilayah di mana putusan arbitrase yang bersangkutan itu telah diucapkan dan didaftarkan. Ketua Pengadilan Negeri setempat yang mengatur cara pelaksanaan dari putusan arbitrase sebagai badan yang sesungguhnya meSUrupakan "Hakim Partikulir", dalam arti putusan arbitrase 
ini bukan dari badan pengadilan, tetapi orang-orang yang dipercaya oleh pihak yang berperkara untuk menjatuhkan putusan yang kemudian mengikat mereka dan harus dilaksanakan.

Berbeda dengan pendapat di atas, Hakim Agung Asikin Kusumaatmadja mengemukakan, bahwa masih perlu cara mengatur bagaimana tata caranya untuk pelaksanaan putusan arbitrase luar negeri di Indonesia. Beliau menganggap perlu bersikap hati-hati karena berhubungan dengan hukum luar negeri. Tidak semua Pengadilan Negeri di Indonesia dianggap dapat mengikuti irama Hukum Dagang Internasional. Ada kekhawatiran bahwa pengadilan-pengadilan negeri setempat, apabila di tempat-tempat terpencil, akan menghadapi kesukaran secara teknis dan praktis dalam pelaksanaan putusan arbitrase luar negeri yang hendak dilaksanakan di dalam wilayah Republik Indonesia ini (Sudargo Gautama, 1991:2).

Selanjutnya, Sudargo Gautama mengatakan, bahwa alasan pengadilan menolak pelaksanaan eksekusi arbitrase asing tercantum dalam putusan Mahkamah Agung. Pertimbangan penolakan eksekusi yang dicantumkan dalam putusan tersebut antara lain menyebutkan "Meskipun sudah ada Keputusan Presiden No. 34 Tahun 1981, putusan arbitrase asing tidak dapat dieksekusi oleh Pengadilan Indonesia, kalau belum ada peraturan pelaksanaannya" (M. yahya Harahap, 1991:59).

Jadi menurut MA., walaupun Indonesia telah meratifikasi Konvensi New York 1958, tidak otomatis putusan arbitrase asing dapat dieksekusi berdasarkan Keppres No. 34 Tahun 1981.
Menurut MA., sesuai dengan praktek hukum yang berlaku, diperlukan lagi peraturan pelaksanaan yang mengatur tentang tata cara eksekusi. Tanpa peraturan pelaksanaan, Pengadilan Indonesia tidak dapat menilai dan mempertimbangkan apakah suatu putusan arbitrase asing mengandung hakhak yang bertentangan dengan hukum atau ketertiban umum yang berlaku di Indonesia. Tanpa mempersoalkan benar atau tidaknya pendapat MA., atas penolakan tersebut, maka sejak berlaku Perma No. 1 Tahun 1990 telah lenyap dan terlampaui hambatan formal eksekusi putusan arbitrase asing. Dalam Oerma telah diatur tata cara dan kewenangan Pemerintah eksekusi atas putusan arbitrase asing. Jalan menuju penyelesaian eksekusi arbitrase asing sudah terbuka, asal putusan tersebut memenuhi persyaratan:

1. Memenuhi asas resiprositas (reciprocity).

2. Menyangkut dunia dagang sesuai dengan hukum dagang Indonesia.

3. Tidak mengandung pertentangan dengan kepentingan umum (M. Yahya Harahap, 1993:226-227)

Dengan keluarnya perma, berakhirlah masa kekosongan hukum tentang pelaksanaan eksekusi putusan arbitrase asing. Jangkauannya tidak hanya meliputi putusan arbitrase asing yang dijatuhkan setelah Perma berlaku, tetapi juga meliputi semua putusan arbitrase asing yang telah ada sebelum Perma dikeluarkan, baik terhadap putusan yang belum pernah diajukan, maupun yang sudah pernah ditolak eksekusinya. Penolakan atau pernyataan eksekusi putusan arbitrase asing tidak dapat 
diterima atas alasan peraturan pelaksanaan belum ada yang terjadi di masa lalu sebelum Perma berlaku, sama sekali tidak menggugurkan sifat kekuatan eksekusi (executorial kracht) yang terkandung di dalam putusan. Permohonan eksekusinya dapat diulang dan diperbaharui. Sikap ini harus dipedomani pihak pengadilan, agar tidak menimbulkan kerugian bagi pihak pemohon eksekusi (M. Yahya Harahap, 1991:61).

\section{Bentuk Kalusula Arbitrase}

Perjanjian arbitrase bersifat suplemen, artinya merupakan perjanjian tambahan yang melengkapi perjanjian pokok atau perjanjian induk. Itu sebabnya, ditinjau dari segi hukum perjanjian, maka persetujuan arbitrase adalah perjanjian "asesor" terhadap perjanjian pokok (M. Yahya Harahap, 1991:99). Selanjutnya dikemukakan, bahwa dalam praktek dan penulisan, persetujuan arbitrase selalu disebut "klausula arbitrase". Penggunaan istilah klausula arbitrase mengandung konotasi, bahwa perjanjian pokok yang bersangkutan diikuti atau dilengkapi dengan persetujuan arbitrase.

Para pihak dalam perjanjian yang menghendaki agar penyelesaian sengketa yang mungkin timbul dari perjanjian itu, diselesaikan dengan peradilan arbitrase dapat mempergunakan salah satu dari dua cara, yang dapat membuka jalan timbulnya peradilan arbitrase yaitu dengan mencantumkan sebuah klausula dalam perjanjian pokok yang berisi, bahwa penyelesaian sengketa yang mungkin timbul dari pelaksanaan perjanjian akan diselesaikan dengan peradilan arbitrase. Cara seperti ini disebut "pactum de compromittendo", atau dengan membuat suatu perjanjian tersendiri, di luar perjanjian pokok. Perjanjian ini dibuat secara khusus, bila telah timbul sengketa dalam melaksanakan perjanjian pokok. Surat perjanjian semacam ini disebut "akta kompromis" (HMN. Purwosutjipto, 1992:6).

\section{Pactum de compromittendo}

Bentuk klausa arbitrase pactum de compromittendo, diatur dalam Pasal 615 ayat (3) Rv dan diatur juga dalam Pasal II ayat (1) Konvensi New York 1958. Bunyi dari ketentuan Pasal 615 ayat (3) Rv., menyebutkan "Adalah diperkenankan mengikat diri satu sama lain untuk menyerahkan sengketa-sengketa yang mungkin timbul dikemudian hari pada putusan seorang atau beberapa orang wasit (arbiter).

Dapat dilihat, dalam klausula arbitrase yang berbentuk pactum de compromittendo, para pihak mengikat kesepakatan akan menyelesaikan persengketaan yang mungkin timbul melalui forum arbitrase. Pada saat mengikat dan menyetujui klausula arbitrase, sama sekali belum terjadi perselisihan. Seolah-olah klausula arbitrase dipersiapkan untuk mengantisipasi perselisihan yang mungkin timbul di masa yang akan datang. Jadi, sebelum terjadi perselisihan yang nyata, para pihak telah sepakat dan mengikat diri untuk menyelesaikan perselisihan yang akan terjadi pada arbitrase. Bentuk klausula arbitrase yang seperti ini disebut "pactum de compromittendo". Dalam Pasal II ayat (1) Knvensi New York 1958 dirumuskan dalam kalimat "... the parties undertake to submit to arbitration all or 
any differences... which may arise between them....".

\section{Akta Kompromis}

Bentuk klausula arbitrase yang kedua adalah akta kompromis, diatur dalam Pasal 618 Rv serta Pasal II ayat (1) Konvensi New York 1958.

Di dalam Pasal 618 Rv disebutkan:

(1) Persetujuan arbitrase harus diadakan secara tertulis dan ditandatangani kedua belah pihak, jika para pihak tidak mampu menandatangani, maka persetujuan harus dibuat di muka notaris.

(2) Persetujuan harus memuat masalah yang menjadi sengketa, nama, dan tempat tinggal para pihak, dan juga nama serta tempat tinggal arbiter atau para arbiter, yang selalu harus dalam jumlah ganjil.

(3) Semua atas ancaman pembatalan.

Dari bunyi pasal di atas dapat dirinci beberapa syarat sahnya suatu akta kompromis yang diatur dalam Pasal 618 Rv yaitu:

1. Pembuatan akta kompromis dilakukan setelah terjadi suatu sengketa.

2. Bentuknya harus dengan akta yang tertulis serta tidak boleh dengan persetujuan lisan.

3. Harus ditandatangani oleh kedua belah pihak, tetapi apabila para pihak tidak bisa menandatangani, maka akta kompromis harus dibuat di depan notaris.

4. Isi akta kompromis dibuat di depan notaris.

a. Masalah yang disengketakan.

b. Nama dan tempat tinggal para pihak. c. Nama dan tempat tinggal para arbiter.

d. Jumlah arbiter harus ganjil.

Berdasarkan Pasal $618 \mathrm{Rv}$ dapat dilihat, akta kompromis sebagai perjanjian arbitrase, dibuat setelah timbul perselisihan di antara para pihak, yang sebelumnya tidak diadakan persetujuan arbitrase. Dalam kasus seperti ini, apabila para pihak menghendaki agar perselisihan diselesaikan melalui forum arbitrase, mereka dapat membuat perjanjian untuk itu. Perjanjian arbitrase yang seperti ini disebut "akta kompromis".

Akta kompromis adalah akta yang berisi aturan penyelesaian perselisihan yang telah timbul di antara orang yang berjanji. Dikaitkan dengan arbitrase, akta kompromis mengandung makna tersendiri yakni perjanjian yang disepakati oleh pihak yang berjanji, bahwa perselisihan yang terjadi di antara mereka diselesaikan melalui forum arbitrase. Dalam pasal II ayat (1) Konvensi New York 1958 dirumuskan dengan: "differences which have arisen" (M. Yahya Harahap, 1991:102).

\section{Beberapa Jenis Lembaga Arbitrase}

Tinjauan terhadap beberapa jenis lembaga arbitrase, dilakukan melalui pendekatan ketentuan perundangundangan dan aturan yang terdapat dalam berbagai konvensi.

Jenis lembaga arbitrase adalah macam-macam arbitrase yang diakui eksistensi dan kewenangannya untuk memeriksa dan memutus perselisihan yang terjadi di antara para pihak yang mengadakan perjanjian (M. Yahya Harahap, 1991:149). 
Jenis lembaga arbitrase yang diakui dan memiliki validitas, diatur dan disebut dalam peraturan dan berbagai konvensi. Dengan demikian, pembicaraan tentang eksistensi jenis lembaga arbitrase, tidak hanya bertitik tolak dari Rv, tetapi juga merujuk kepada kepada Convention of The Settlement of Investment Disputes Between States and National of Other States (ICSID), Convention on The Recognition And Enforcement of Foreign Arbitral Awards (Konvensi New York 1958), serta UNCITRAL Arbitration Rules.

Beberapa jenis lembaga arbitrase tersebut antara lain:

\section{Arbitrase ad hoc.}

Arbitrase ad hoc dalam Pasal I ayat (1) Konvensi New York 1958 dirumuskan dengan istilah "arbitrators appointed for each case" yang bermakna: "arbiter yang ditunjuk untuk kasus tertentu untuk satu kali penunjukan". Dalam ketentuan ini jelas dapat dilihat sifat insidentil yang melekat pada lembaga arbitrase ad hoc. Hal ini dapat disimak dari perkataan "appointed for each case". Penunjukan dan keberadaannya adalah kasus perkasus. Fungsi dan kewenangannya bersifat satu kali (een malig).

Mengenai cara penunjukan arbiter dalam arbitrase ad hoc dapat dilakukan sendiri atas kesepakatan para pihak. Jika arbiternya tunggal, pengangkatannya atas persetujuan bersama para pihak. Apabila arbiternya lebih dari seorang maka masing-masing pihak menunjuk seorang anggota arbiter yang ketiga, pengangkatannya dapat dilakukan atas kesepakatan bersama atau menyerahkannya kepada kesepakatan arbiter yang telah ditunjuk para pihak. Selain dari cara penunjuk arbiter yang disebutkan di atas, boleh juga para pihak menyerahkan kepada Pengadilan Negeri. Jika cara ini yang mereka tempuh, hakim berwewenang mengangkat arbiter yang diminta oleh salah satu pihak. Hal ini berdasarkan ketentuan Pasal 13 ayat (2) UU No.30 Tahun 1999 yang berbunyi:

Apabila, dalam hal seperti yang diterangkan dalam ayat (3) Pasal 615, pada waktu sengketa timbul, para pihak yang tidak mencapai sepakat tentang hal memilih arbiternya, maka atas permohonan pihak yang paling berkepentingan, arbiter atau para arbiter itu akan diangkat oleh hakim yang sedianya berwenang memeriksa sengketanya seandainya tidak ada persetujuan arbitrase.

\section{Arbitrase institusional}

Arbitrase institusional (institusional arbitration) merupakan lembaga arbitrase yang bersifat permanen. Oleh karena arbitrase institusional merupakan badan bersifat permanen yang disebut juga "permanen arbitral bodies" dalam Konvensi New York (Pasal I ayat (2).

Arbitrase institusional ialah badan arbitrase yang sengaja didirikan. Pemebentukannya ditujukan untuk menangani sengketa yang timbul bagi mereka yang menghendaki penyelesaian di luar pengadilan. Ia merupakan badan yang sengaja didirikan untuk menampung perselisihan yang timbul dari perjanjian.

Perbedaan lain, arbitrase institusional tetap berdiri untuk selamanya dan tidak bubar meskipun perselisihan yang ditangani telah selesai diputus. Sebaliknya arbitrase ad hoc akan bubar dan berakhir keberadaannya 
setelah sengketa yang ditangani selesai diputus. Selain dari hal-hal yang diutarakan, arbitrase institusional sengaja didirikan sebagai badan yang bersifat permanen, sekaligus disusun organisasinya serta ketentuan-ketentuan tentang tata cara pengangkatan arbiter, maupun tata cara pemerikasaan persengketaan.

Lembaga arbitrase institusional berdasarkan sifatnya terdiri dari:

\section{a. Arbitrase institusional yang bersifat nasional}

Arbitrase institusional merupakan badan (body) yang sengaja didirikan sebagai wadah permanen. Jika kesengajaan pendiriannya hanya untuk kepentingan suatu bangsa atau negara, arbitrase institusional tersebut dinamakan bersifat nasional (M. Yahya Harahap, 1991:152). Ruang lingkup keberadaan dan yuridiksinya hanya meliputi kawasan negara yang bersangkutan. Misalnya lembaga arbitrase institusional Badan Arbitrase Nasional Indonesia yang disingkat dengan BANI, merupakan badan arbitrase yang berwawasan nasional Indonesia. Ruang lingkup keberadaan dan yuridiksinya hanya meliputi kawasan wilayah Indonesia. Akan tetapi walaupun BANI nersifat nasional, bukan berarti BANI hanya berfungsi menyelesaikan sengketa-sengketa yang bertarap nasional. BANI dapat juga menyelesaikan sengketasengketa yang bertaraf internasional, asal hal itu diminta dan disepakati oleh para pihak.

\section{b. Arbitrase institusional yang bersifat internasional.}

Selain arbitrase institusional yang bersifat nasional, ada juga arbitrase institusional yang berwawasan internasional. Bahkan badan-badan arbitrase institusional tersebut sudah lama didirikan. Salah satu badan arbitrase internasional yang tertua di antaranya "Court of Arbitration of The International Chamber of Commerce" yang disingkat ICC. Badan arbitrase ini didirikan di Paris pada tahun 1919.

Pada dasarnya badan-badan arbitrase yang berwawasan international, merupakan pusat perwasitan dalam menyelesaikan persengketaan di bidang masalah tertentu, antara para pihak yang berlainan kewarganegaraannya. Seperti ICC adalah pusat arbitrase internasional yang khusus menangani penyelesaian persengketaan antara para pihak yang berlainan kewarganegaraan di bidang perdagangan umumnya.

Selain ICC, badan arbitrase yang berwawasan internasional yang paling menonjol ialah "The International Centre for Settlement of Invesment of Invesment Disputes Between States and Nationals of Others States Centre menjadi pusat arbitrase internasional, khusus untuk menyelesaikan persengketaan joint venture atau penanaman modal antar suatu negara dengan warga negara asing.

Pada bagian pembukaan, konvensi tersebut menjelaskan bahwa didirkannya Center (ICSID) merupakan kebutuhan kerjasama internasional (the need for international cooperation) dalam perkembangan perekonomian dan sebagai aturan main dalam penanaman modal di sektor swasta. Hal ini sehubungan dengan pemikiran tentang berbagai kemungkinan timbulnya perbedaan pendapat (disputes), berkenaan dengan penanaman modal di antara anggota negara peserta konvensi (contracting states). 
Selanjutnya contoh lain dari lembaga arbitrase institusional yang berwawasan internasional adalah "UNCITRAL Arbitration Rules (United Nation Commission on International Trade Law)" yang lazim disingkat dengan UAR. UNCITRAL Arbitration on Rules berlaku berdasarkan resolusi siding umum PBB pada tanggal 15 Desember 1976. Resolusi tersebut berisi anjuran kepada dunia arbitrase agar dalam melaksanakan kegiatan arbitrase dipergunakan dan diterapkan UNCITRAL Arbitration Rules. UNCITRAL Arbitration on Rules disusun oleh panitia $\mathrm{PBB}$, berisi peraturan mengenai arbitrase yang dianggap dapat diterima oleh segala pihak masyarakat internasional yang system hukum dan sosialnya berbeda. Indonesia termasuk salah satu negara yang ikut menandatangani resolusi. Dengan demikian rules tersebut sudah termasuk dalam system tata hukum nasional Indonesia.

\section{c. Arbitrase institusional yang bersifat regional.}

M. Yahya Harahap (1991:154) menyatakan, bahwa ada kecenderungan dan anggapan dari kalangan negara dunia ketiga yang masih tergolong masyarakat yang sedang berkembang, putusanputusan yang dijatuhkan badan arbitrase internasional yang berpusat di negaranegara Barat, sangat didominasi oleh kepentingan negara-negara maju. Seolaholah putusan yang diambil badan arbitrase internasional yang notabene anggota arbiternya selalu diangkat dari kalangan negara maju itu sendiri, dirasakan lebih memihak membela kepentingan negaranegara maju.
Lebih lanjut M. Yahya Harahap kemukakan (1991:155-156), bahwa pengalaman yang demikian mendorong kawasan dunia ketiga, untuk mendirikan pusat-pusat arbitrase institusional yang berwawasan regional. Berkumpullah kelompok ahli dari dunia ketiga dalam suatu wadah organisasi yang diberi nama "Asia Afrika Legal Consultative Committee, yang disingkat AALCC serta berkantor pusat di New Delhi India. Gerakan kelompok ini berusaha melepaskan diri dari dominasi ICC, dengan jalan mendirikan pusat arbitrase sendiri.

Sebagai lanjutan usaha mendirikan pusat arbitrase regional bagi kawasan dunia ketiga, maka pada tahun 1978 diadakan pertemuan di Kuala Lumpur, Malaysia. Pada pertemuan AALCC tersebut, berhasil direalisir berdirinya pusat arbitrase untuk kawasan Asia yang berkedudukan di Kuala Lumpur. Perkembangan selanjutnya, pada pertemuan tahun 1979 berhasil pula didirikan pusat arbitrase regional untuk kawasan negara-negara Afrika yang berkedudukan di kairo, Mesir.

Sepertinya, tujuan utama mendirikan pusat-pusat badan arbitrase oleh AALCC dimaksudkan untuk melepaskan diri dari dominasi ICC. Bukan untuk memencilkan diri dari pergaulan dunia internasional.

\section{Beberapa Hal Pokok dalam Arbitrase}

Tinjauan terhadap beberapa hal pokok dalam arbitrase meliputi: persetujuan arbitrase, wasit (arbiter), pilihan hukum (choice of law) serta eksekusi putusan arbitrase.

Dapat dikemukakan, bahwa di masa sekarang ini pihak asing cenderung 
mengadakan suatu hubungan bisnis yang diikat dengan suatu perjanjian arbitrase.

Tata cara pemeriksaan dan penyelesaian perkara melalui lembaga arbitrase adalah sebagai berikut:

\section{Persetujuan arbitrase.}

Keinginan para pihak yang bersifat sukarela merupakan unsur penting adanya lembaga arbitrase. Dalam setiap permohonan penyelesaian sengketa melalui lembaga arbitrase, harus diteliti lebih dahulu yang menjadi dasarnya, yaitu terdapat kesepakatan tertulis para pihak untuk menyelesaikan sengketa melalui arbitrase, bukan ke pengadilan. Tanpa adanya kesepakatan ini, maka penyelesaian sengketa melalui arbitrase tidak mempunyai kekuatan yang mengikat.

Gary Goodpaster (1995:4 bahan kuliah S2) menyatakan, bahwa pihakpihak yang setuju untuk meyelesaikan secara arbitrase dapat memilih: jenis sengketa yang akan diarbitrasekan, metode dalam memilih wasitnya, ketentuan-ketentuan prosedural arbitrase, tempat arbitrase dilaksanakan, dan hukum yang berlaku terhadap sengketa tersebut (parties who agree to arbitrate may choose: the kinds of disputes to arbitrated, the method for choosing the arbitrators, the procedural arbitration, the place of the arbitration, and the substantive law applicable to the dispute).

Pembentukan mahkamah arbitrase (arbitral tribunal) bersumber dari kesepakatan para pihak, yang dituangkan dalam klausula arbitrase baik yang berbentuk pactum de compromittendo atau dalam akta kompromis. Dalam perjanjian arbitrase, para pihak dapat menyepakati penunjukan badan arbitrase institusional atau arbitrase ad hoc. Serta dapat pula menentukan arbiter yang akan berfungsi menyelesaikan sengketa, arbiter tunggal (solo arbiter) atau bersifat majelis yang terdiri dari tiga orang. Pembentukan mahkamah arbitrase termasuk salah satu bagian dari proses pemeriksaan arbitrase, terutama apabila arbitrase yang disepakati para pihak berupa arbitrase institusional.

Berkenaan dengan persetujuan arbitrase, Badan Arbitrase Nasional Indonesia (BANI) menyarankan kepada para pihak yang ingin menggunakan jasa BANI, untuk mencantumkan dalam perjanjian mereka suatu klausula standar yang menyebutkan "Semua sengketa yang timbul dari perjanjian ini akan diselesaikan dalam tingkat pertama dan terakhir menurut prosedur BANI oleh arbiter yang ditunjuk menurut peraturan tersebut" (R. Subekti, 1981:11).

\section{Wasit (arbiter)}

Dalam hal ini, istilah yang dipergunakan bermacam-macam meskipun mempunyai maksud yang sama, di antaranya: wasit, arbiter, scheidsman, penengah, dan juru pisah. Pasal $617 \mathrm{Rv}$ menyebutkan:

(1) Dengan pengecualian sebagaimana termuat dalam ketentuan Pasal 34, maka siapa saja yang diperbolehkan menjadi seorang kuasa, juga diperbolehkan untuk diangkat sebagai seorang wasit.

(2) Dari ketentuan ini dikecualikan wanita dan anak yang belum dewasa. (Pasal $34 \mathrm{Rv}$ ialah melarang para hakim, jaksa, dan panitera pengadilan untuk menjadi juru kuasa dan wasit).

Ketidakmampuan atau tidak cakapnya wanita untuk menjadi arbiter sudah tidak sesuai dengan perkembangan 
zaman, hal ini dapat dilihat dari banyak wanita Indonesia telah menjadi dosen, notaris, dokter, profesor, bahkan menteri, serta posisi penting lainnya. Hal ini juga dipertegas dengan keluarnya SEMA No. 13 Tahun 1963.

Berdasarkan Pasal 14 ICSID, syaratsyarat yang harus dimiliki seorang arbiter adalah:

a. Memliki karakter yang tinggi (persons of high moral character).

b. Memliki kemampuan yang tinggi di bidang hukum, perdagangan, industry, dan keuangan (recognized competence in the fields of law, commerce, industry or finance).

c. Mampu mengadakan penilaian dan memberi putusan yang bebas dari pengaruh orang lain (independent judgment).

Seorang arbiter harus dapat bersikap independen, selain untuk menjaga reputasinya serta untuk menjaga jangan sampai arbiter yang ditunjuk negaranya merasa berkewajiban menjatuhkan putusan yang menguntungkan negaranya.

Pengangkatan atau penunjukan arbiter pada dasarnya ditentukan oleh para pihak di dalam akta kompromis atau pactum de compromittendo.

Dalam konvensi ICSID, yang melakukan penunjukan arbiter dalam ICSID. Boleh saja satu arbiternya (a sole arbitrator) atau beberapa orang arbiter asalkan jumlahnya ganjil (any uneven number of arbitrators). Meskipun pengangkatan arbiter menjadi wewenang ICSID, namun harus mendapat persetujuan oleh kedua belah pihak (the parties shall agree). Dalam hal ini ada kewenangan yang seimbang antara ICSID dengan para pihak dalam penunjukan arbiter, karena para pihak yang diberikan hak untuk mengajukan keberatan atas pengangkatan arbiter (M. Yahya Harahap, 1991:174

\section{SIMPULAN}

Lembaga arbitrase di kalangan pelaku usaha di Kota Medan telah dikenal atau telah dipergunakan dalam keadaan bisnis, tetapi keberadaannya masih sebatas turut dicantumkan dalam perjanjian bisnis, hal ini disebabkan beberapa faktor yaitu:

a. Walaupun umumnya keberadaaan lembaga arbitrase sudah diketahui kalangan pelaku usaha, tetapi pemahaman pelaku usaha terhadap lembaga penyelesaian sengketa alternatif masih sangat minim.

b. Ada kelaziman dikalangan pelaku usaha, walaupun didalam kontrak bisnis telah terdapat klausula arbitrase, tetapi penyelesaian sengketa melalui jalan musyawarah (negosiasi) lebih didahulukan, sehingga belum pernah terjadi penyelesaian sengketa bisnis diselesaikan melalui lembaga arbitrase.

Pelaku usaha di Kota Medan lebih meminati lembaga arbitrase yang berbentuk institusional dengan alasan utamanya, bahwa arbiter yang akan menyelesaikan sengketa bisnis telah disediakan oleh badan arbitrase institusional yang akan menyelesaikan sengketa tersebut. Selanjutnya, Badan Arbitrase Nasional Indonesia (BANI) merupakan badan arbitrase institusional yang paling diminati kalngan pelaku usaha dengan alasan utama, bahwa pelaku usaha 
telah mengenal Badan Arbitrase Nasional Indonesia (BANI).

Lembaga arbitrase kurang dipergunakan kalangan pelaku usaha di dalam menyelesaikan sengketa bisnisnya, disebabkan beberapa faktor, antara lain: pelaku usaha kurang memahami keberadaan lembaga arbitrase, peraturan umum arbitrase Indonesia sudah tidak sesuai dengan perkembangan dunia bisnis, dan kurangnya tenaga ahli (expert) di bidang arbitrase, baik dari segi kualitas maupun kuantitas. Selain faktor-faktor tersebut, berdasarkan data yang diperoleh, bahwa di dalam kontrak bisnis yang terdapat di kalangan pelaku usaha di Kota Medan, masih ditemukan klausula arbitrase yang bersifat ragu-ragu atau memerlukan penafsiran lebih lanjut, dalam hal lembaga mana yang akan menyelesaikan sengketa bisnis para pihak, lembaga arbitrase atau badan pengadilan (litigation). Klausula tersebut dapat mempersulit penggunaan lembaga arbitrase.

\section{DAFTAR PUSTAKA}

A. Buku-buku

Adolf, Huala, 1994, Hukum Arbitrase Komersial Internasional, P.T. Raja Grafindo Persada, Jakarta.

Gautama, Sudargo, 1974, Capita Selecta Hukum Perdata Internasional, Alumni, Bandung.

Gautama, Sudargo, 1976, Kontrak Dagang Internasional (Himpunan Ceramah Dan Prasaran), Alumni, Bandung.

Gautama, Sudargo, 1986, Arbitrase Dagang Internasional, Alumni, Bandung.

Gautama, Sudargo, 1991, Hukum Dagang \& Arbitrase Internasional, P.T. Citra Aditya Bakti, Bandung.

Goodpaster, Gary, Agnes M. Toar, Fatmah Jatim, Felix O. Soebagjo, H. Aminuddin Salle, HMG. Ohorella, Lelly Niwan, Noegroho Amien Soetiarto, Roedjino, 1995, Arbitrase Di Indonesia, Ghalia Indonesia, Jakarta.

Harahap, M. Yahya, 1991, Arbitrase, Pustaka Kartini, Jakarta.
Harahap, M. Yahya, 1993, Perlawanan Terhadap Eksekusi Grose Akta Serta Putusan Pengadilan Dan Arbitrase Dan Standar Hukum Eksekusi, P.T. Citra Aditya Bakti, Bandung.

Purwosutjipto, HMN., 1992, Pengertian Poko Hukum Dagang Indonesia 8, Penerbit Djambatan, Jakarta.

Subekti, R., 1981, Arbitrase Perdagangan, Binacipta, Jakarta.

Umar, M. Husseyn dan A. Supriyani Kardono, 1995, Hukum Dan Lembaga Arbitrase di Indonesia, ELIPS, Jakarta.

\section{B. Makalah dan Jurnal}

Goodpaster, Gary, Felix O. Soebagjo, Fatmah Jatim, 1995, Tinjauan Terhadap Arbitrase Dagang Secara Umum dan Arbitrase Dagang di Indonesia, Bahan Lokakarya, Medan. Hukum Bisnis, Jurnal, Volume 2, 1997.

Pangaribuan. C.B., (2016), Kewenangan Pengadilan dalam Penyelesaian Sengketa Kepemilikan PT. Televisi Pendidikan Indonesia (PT. TPI) yang Memuat Klausul Arbitrase (Studi Kasus Putusan Nomor 238 PK/pdt/2014), Mercatoria, 9 (1): 72-83.

Sukwanto, B., dan Taufik S., (2010),Pelaksanaan Putusan Arbitrase Internasional Di Indonesia, Mercatoria, 3 (1):1 - 19.

UU. No. 30 Tahun 1999

Hukum Bisnis, Jurnal, Volume 2, 1997.

UU. No. 30 Tahun 1999

UU No. 14 Tahun 1970

UU No. 14 Tahun 1985

UU No. 5 Tahun 1968 